\title{
PENGEMBANGAN MEDIA PEMBELAJARAN APLIKASI ANDROID PYTHA FUN UNTUK TEOREMA PYTHAGORAS SMP
}

\author{
Yohanes Suhendi Pangestu' ${ }^{1}$, Danang Setyadi ${ }^{2}$ \\ 1,2,3 Universitas Kristen Satya Wacana, J1 Diponegoro 52-60 Salatiga, Indonesia \\ 202016016@student.uksw.edu
}

\begin{abstract}
There are students who tend to memorize the Pythagorean theorem. This is due to the difficulty of understanding the Pythagorean theorem so that it needs to be developed learning media for android applications. This study aims to develop learning media in the form of an android application on the Pythagorean theorem material. This research is a research development. The research model used is ADDIE. The results showed that the learning media developed by Android applications met the validity index $\geq 68 \%$. The percentage of results of media validation was $79.99 \%$ with a good category and material validation was $88.89 \%$ with a very good category. The product trial results show that the android application learning media developed can improve student learning outcomes in the Pythagorean theorem material, this is indicated by the increase in the average pre-test 55.83 to 86.93 in the post-test.
\end{abstract}

Keywords: Media Development, Adobe Flash, Android, Pythagorean Theorem

\begin{abstract}
Abstrak
Terdapat siswa yang cenderung menghafal teorema Pythagoras. Hal ini disebabkan karena adanya kesulitan memahami teorema Pythagoras sehingga perlu dikembangkan media pembelajaran aplikasi android. Penelitian ini bertujuan untuk mengembangkan media pembelajaran berupa aplikasi android pada materi teorema Pythagoras. Penelitian ini adalah penelitian pengembangan. Model penelitian yang digunakan adalah ADDIE. Hasil penelitian menunjukkan bahwa media pembelajaran aplikasi android yang dikembangkan memenuhi indeks kevalidan $\geq 68 \%$. Persentase hasil validasi media sebesar 79,99\% dengan kategori baik dan validasi materi sebesar $88,89 \%$ dengan kategori sangat baik. Hasil uji coba produk menunjukkan bahwa media pembelajaran aplikasi android yang dikembangkan mampu meningkatkan hasil belajar siswa pada materi teorema Pythagoras, hal ini ditunjukkan oleh meningkatnya rata-rata pre test 55,83 menjadi 86,93 pada post test.
\end{abstract}

Kata Kunci: Pengembangan Media, Adobe Flash, Android, Teorema Pythagoras

Teorema Pythagoras menyatakan bahwa pada setiap segitiga siku-siku berlaku kuadrat panjang sisi miring (hipotenusa) sama dengan jumlah kuadrat panjang sisi-sisi siku-sikunya (Husain, 2005). Teorema ini ditemukan oleh Pythagoras von Samos, seorang ahli matematika berkebangsaan Yunani yang hidup pada abad keenam Masehi dan berkesempatan memperdalam ilmunya di Babilonia (Adinawan dan Sugiyono, 2008: 92).

Teorema Pythagoras menjadi salah satu materi yang diajarkan pada jenjang kelas VIII SMP. Materi ini sangat terkait erat dengan lingkaran dan bangun ruang sisi datar kelas VIII SMP. Salah satu masalah yang dihadapi dalam mempelajari teorema pythagoras adalah kecenderungan siswa untuk menghafal rumus teorema Pythagoras bukan memahami bagaimana hubungan sisi miring (hipotenusa) dengan kedua sisi siku-siku dalam teorema Pythagoras. Hal ini didukung oleh Jamilah (2013 : 4) menyatakan bahwa siswa mengalami kesulitan dalam memahami hubungan sisi miring (hipotenusa) dengan kedua siku-siku sehingga siswa cenderung menghafal rumus teorema Pythagoras, Kondisi tersebut dapat diatasi dengan menggunakan media pembelajaran yang tepat. Salah satu media pembelajaran yang dapat dikembangkan adalah media pembelajaran aplikasi android dengan menggunakan software Adobe Flash. 
Adobe Flash adalah software yang memiliki kegunaan menggambar sekaligus membuat animasinya (Wardana H.A , 2016). Penelitian media pembelajaran matematika berbasis Adobe Flash telah dilakukan oleh beberapa peneliti diantaranya yang dilakukan oleh Widyanto dan Kurniasari (2016), Yuliana dkk (2018), Muyaroah (2017) dan Rahmawati (2014) menghasilkan media pembelajaran berbasis aplikasi. Hasil penelitian tersebut menunjukkan bahwa media yang dikembangkan valid, praktis, dan efektif untuk digunakan dalam proses pembelajaran matematika materi teorema Pythagoras. Namun demikian ada beberapa kelemahan media yang telah dikembangkan seperti masih menggunakan action script 2.0 sehingga media tersebut tidak dapat dioperasikan dalam smartphone android. Hal inilah yang mendorong dilakukannya penelitian dengan judul Pengembangan Media Pembelajaran Aplikasi Android Pytha Fun pada materi Teorema Pythagoras. Media pembelajaran yang dikembangkan berbentuk aplikasi pada system operasi android. Penelitian ini bertujuan untuk mengembangkan media pembelajaran yang valid, praktis, dan efektif.

\section{METODE}

Penelitian ini adalah penelitian pengembangan atau Research and Development. Model penelitian yang digunakan adalah model ADDIE yang terdiri dari 5 tahap yaitu Analyze, Design, Development, Implementation, dan Evaluation (Branch, 2014). Subjek penelitian yaitu siswa kelas VIII C SMP Negeri 1 Salatiga yang berjumlah 30 siswa. Instrumen pengumpulan data berupa lembar tes dan lembar pendapat siswa. Teknik analisis data berupa analisis kevalidan, analisis kepraktisan dan analisis keefektifan.

\section{HASIL}

\section{Tahap Analysis (Analisis)}

Tahap analisis terdiri dari analisis kinerja dan analisis kebutuhan. Berdasarkan analisis kinerja diperoleh bahwa kurikulum yang digunakan kelas VIII C adalah kurikulum 2013 Revisi 2018. Materi teorema Pythagoras merupakan materi yang diajarkan pada kelas VIII semester 2 yang terdiri dari beberapa Kompetensi Dasar (KD) yaitu: (1) Menjelaskan dan membuktikan teorema Pythagoras dan tripel Pythagoras (2) Menyelesaikan masalah yang berkaitan dengan teorema Pythagoras dan tripel Pythagoras.

Hasil analisis kebutuhan menunjukkan bahwa media pembelajaran yang dibutuhkan adalah media pembelajaran berbasis aplikasi interaktif yang berisi materi dan latihan soal yang dikemas dalam bentuk aplikasi android yang bersifat melatih kemandirian siswa dalam belajar. Media pembelajaran ini diharapkan dapat mewujudkan pembelajaran matematika yang menarik, praktis, dan menyenangkan. 
Pengembangan Media Pembelajaran Aplikasi Android Pytha Fun Untuk Teorema Pythagoras SMP, Yohanes Suhendi Pangestu $^{1}$, Danang Setyadi ${ }^{2}$

\section{Tahap Design (Desain)}

Tahap desain merupakan tahap dimulainya pembuatan media pembelajaran. Beberapa hal yang didesain antara lain : (1) Nama aplikasi (2) latar atau background aplikasi (3) logo aplikasi dan jenis huruf (4) tombol dalam aplikasi (5) cara kerja aplikasi. Media pebelajaran berbasis aplikasi android ini bernama Pytha Fun yang merupakan kepanjangan dari Pythagoras Fun yang memiliki arti Pythagoras yang lucu dan menyenangkan. Latar atau background aplikasi terdiri dari kombinasi warna, sedangkan logo aplikasi android ini adalah sebuah karakter lucu berbentuk segitiga yang bernama Pytha yang menjadikan aplikasi ini bernuansa santai dan menyenangkan.

\section{Tahap Development (Pengembangan)}

Pengembangan media pembelajaran berbasis aplikasi menggunakan software Adobe Flash. Adobe Flash merupakan software grafis yang digunakan untuk membuat aplikasi dan animasi. Media pembelajaran berbasis aplikasi android ini terdiri dari halaman pembuka dan halaman menu utama. Halaman pembuka memiliki tampilan yang dapat dilihat pada Gambar 1. Pada halaman ini siswa diminta untuk menekan tombol "mulai" yang berada pada bagian bawah untuk menuju ke menu utama.

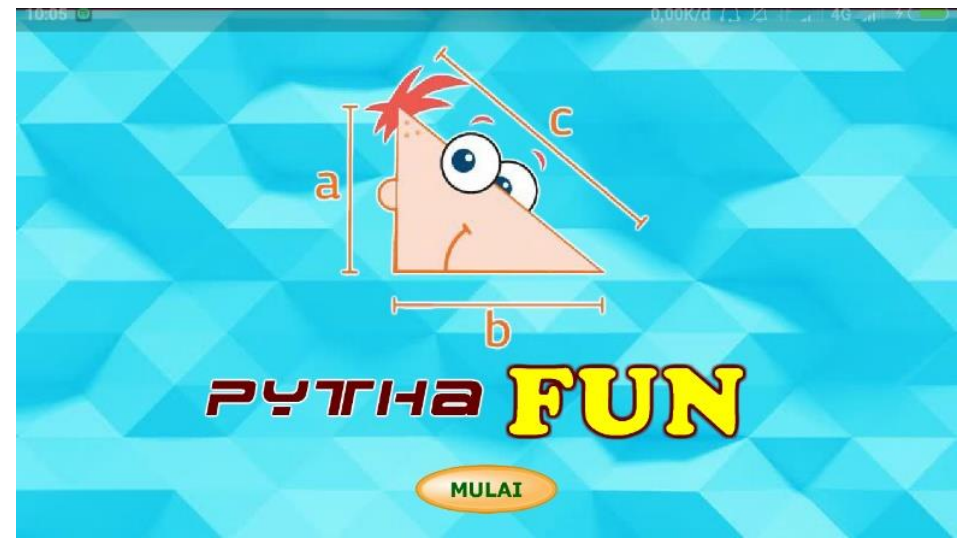

Gambar 1. Tampilan Halaman Pembuka

Setelah menekan tombol "Mulai" maka akan tampil menu utama pada aplikasi ini. Tampilan ini berisi 5 menu utama yaitu Petunjuk, Kompetensi, Materi, Evaluasi dan Profil. Tampilan menu utama dapat dilihat pada Gambar 2.

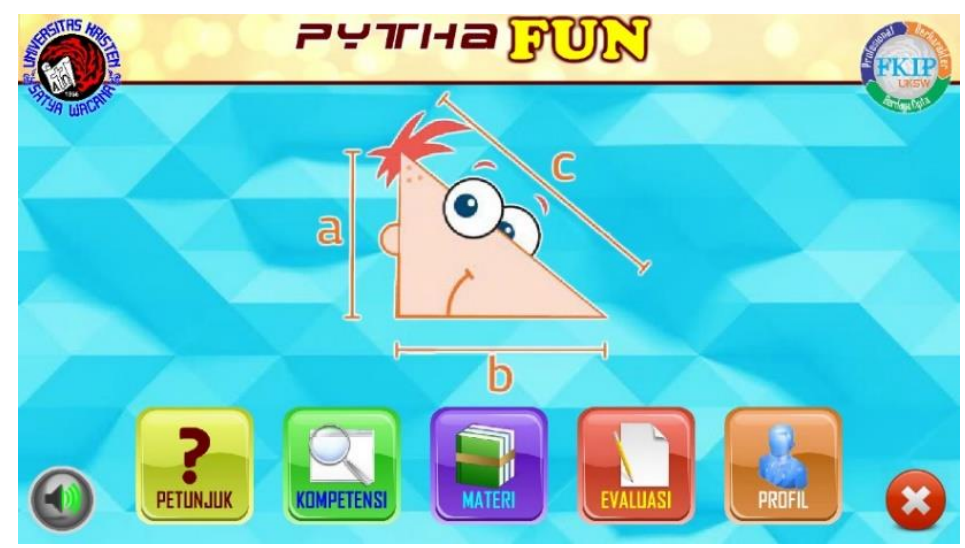

Gambar 2. Tampilan Menu Utama 
Tampilan menu petunjuk penggunaan yang terdiri dari penjelasan singkat tentang isi media pembelajaran dan penjelasan tentang tombol-tombol dapat dilihat pada gambar 3 .

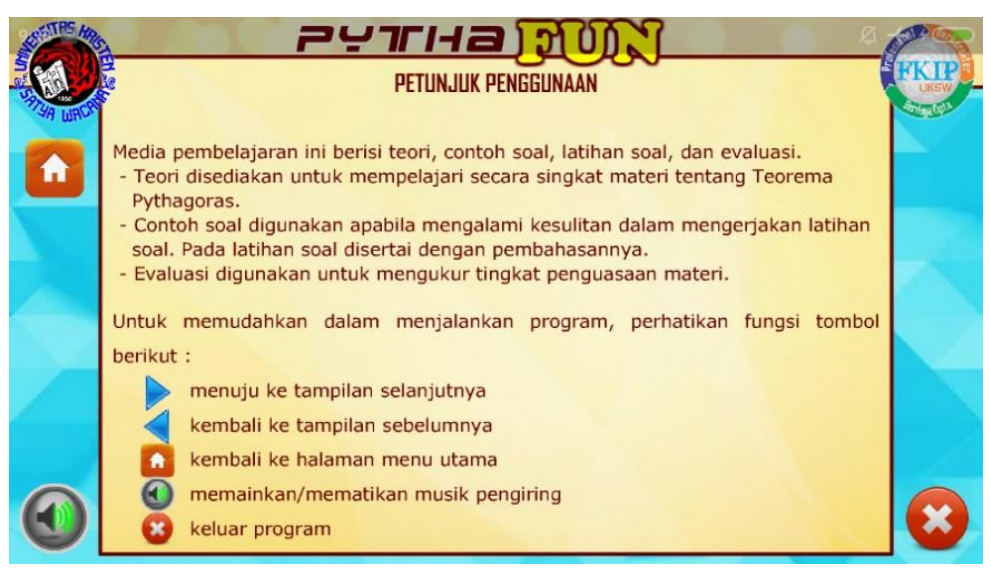

Gambar 3. Petunjuk Penggunaan

Tampilan menu Kompetensi

Setelah menekan tombol "Kompetensi" maka akan muncul Kompetensi Inti yang berisi 1) Menghargai dan menghayati ajaran agama yang dianutnya. 2) Menunjukkan perilaku jujur, disiplin, tanggung jawab, peduli (toleran, gotong royong), santun, dan percaya diri dalam berinteraksi secara efektif dengan lingkungan sosial dan alam dalam jangkauan pergaulan dan keberadaannya. 3) Memahami dan menerapkan pengetahuan (faktual, konseptual, dan prosedural) berdasarkan rasa ingin tahunya tentang ilmu pengetahuan, teknologi, seni, budaya terkait fenomena dan kejadian tampak mata. 4) Mengolah, menyaji dan menalar dalam ranah konkret (menggunakan, mengurai, merangkai, memodifikasi, dan membuat) dan ranah abstrak (menulis, membaca, menghitung, menggambar, dan mengarang) sesuai dengan yang dipelajari di sekolah dan sumber lain yang sama dalam sudut pandang/teori.

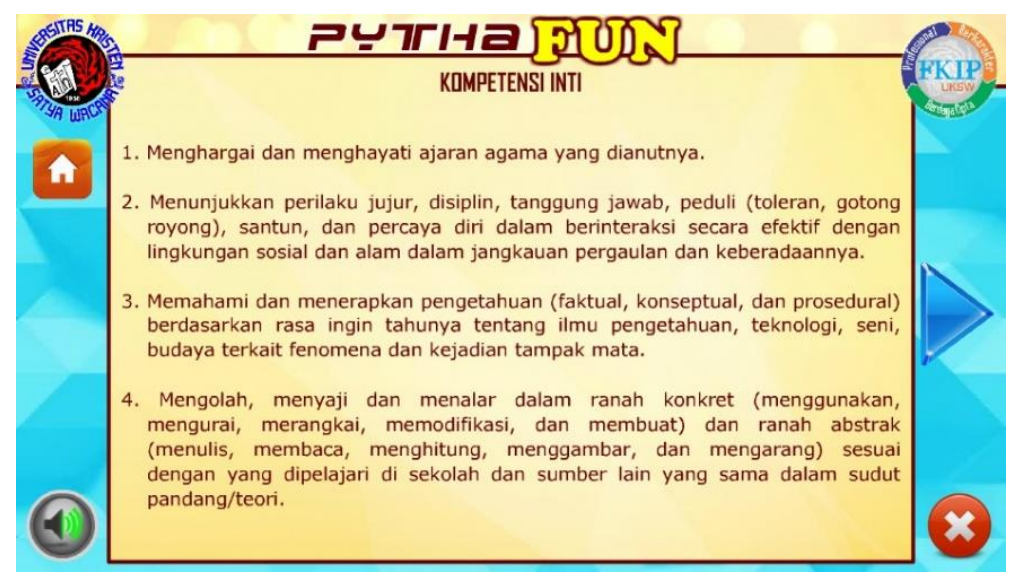

Gambar 4. Kompetensi Inti

Pada Gambar 5 menampilkan Kompetensi Dasar yang berisi menjelaskan dan membuktikan teorema Pythagoras dan tripel Pythagoras serta menyelesaikan masalah yang berkaitan dengan teorema Pythagoras dan tripel Pythagoras. 


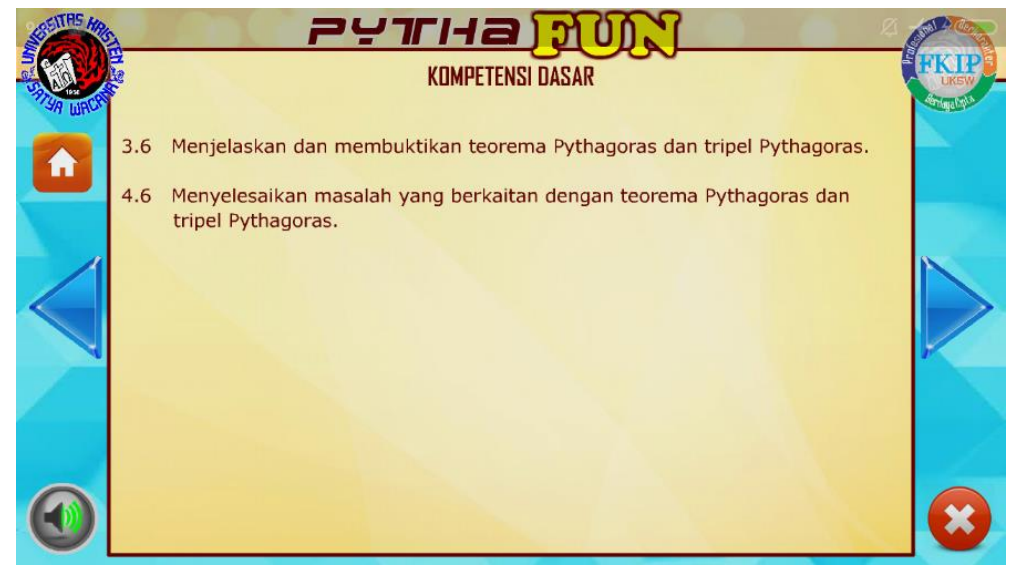

Gambar 5. Kompetensi Dasar

Pada Gambar 6 menampilkan Indikator yang berisi 1) Menemukan rumus teorema Pythagoras yang cocok dengan gambar yang diberikan. 2) Menghitung Panjang sisi miring segitiga siku-siku jika diketahui dua sisi yang lain. 3) Menentukan jenis segitiga jika diketahui Panjang sisi-sisinya. 4) Menghitung Panjang diagonal sisi dan diagonal ruang kubus dan balok. 5) Mengaplikasikan teorema Pythagoras untuk memecahkan masalah terkait menentukan jarak atau tinggi benda.

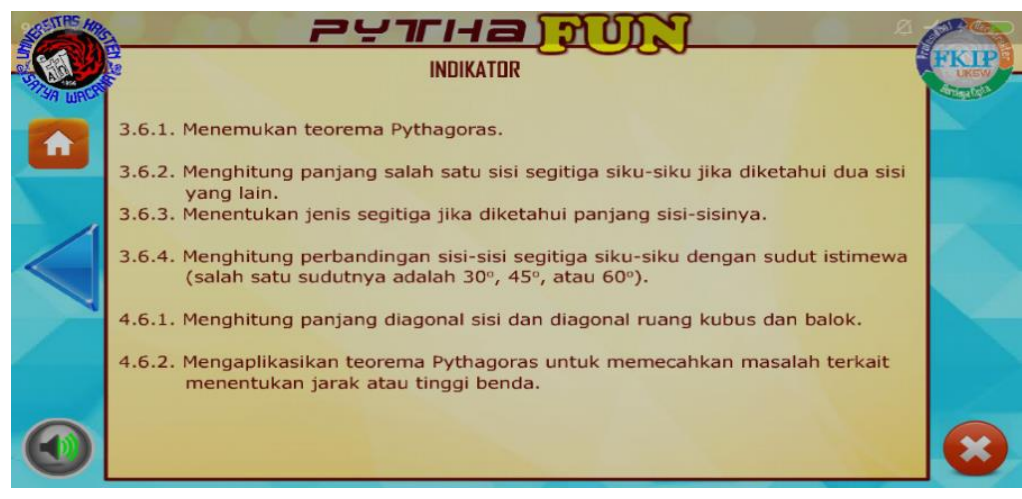

Gambar 6. Indikator

Setelah menekan tombol Materi , siswa dapat langsung mempelajari materi "Menemukan teorema Pythagoras" dengan mengklik gambar segitiga berwarna hijau lalu mengerjakan latihan soal dengan mengisi jawaban pada kotak-kotak yang telah disediakan. Terdapat tombol "Cek Jawaban" untuk mengecek jawaban. Untuk mengganti materi atau menuju materi selanjutnya dapat menekan tombol "Pilih Materi".

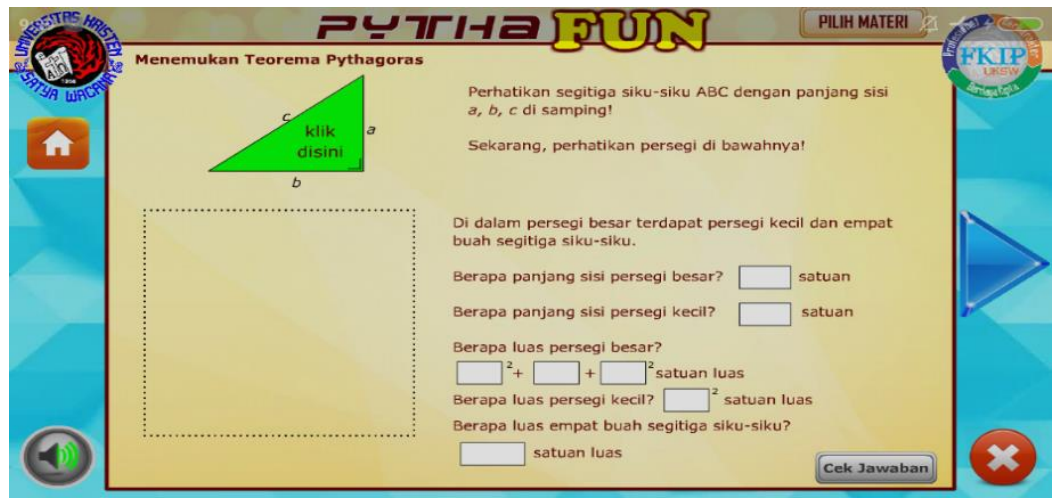

Gambar 7. Materi 
Tampilan menu Evaluasi

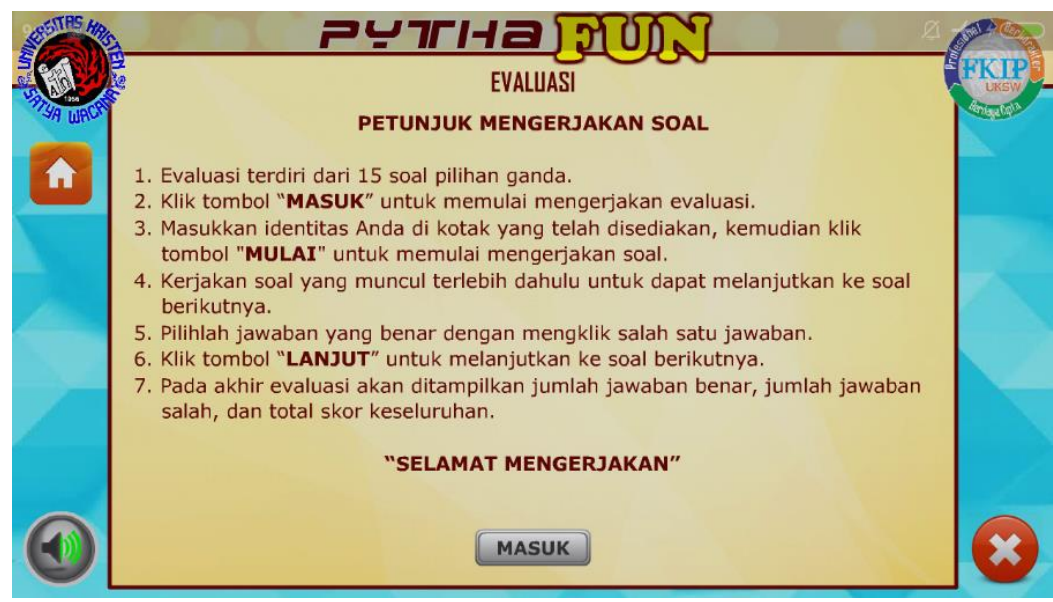

Gambar 8. Evaluasi

Setelah menekan tombol Evaluasi akan muncul petunjuk mengerjakan soal, dan ada tombol "Masuk" untuk memulai mengerjakan soal. Setelah siswa menekan tombol "Masuk" maka akan tampil kotak-kotak yang dapat diisi identitas siswa.

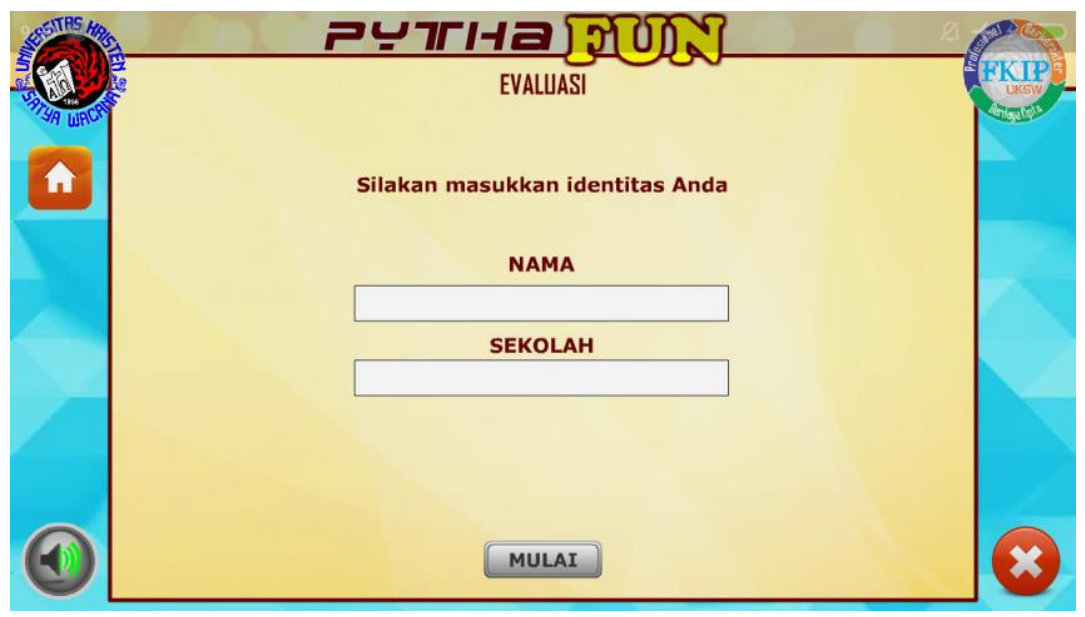

Gambar 9. Evaluasi

Setelah mengisi identitas dapat menekan tombol "Mulai" untuk memulai mengerjakan soal Evaluasi. Soal Evaluasi berbentuk pilihan ganda berjumlah 15 soal.

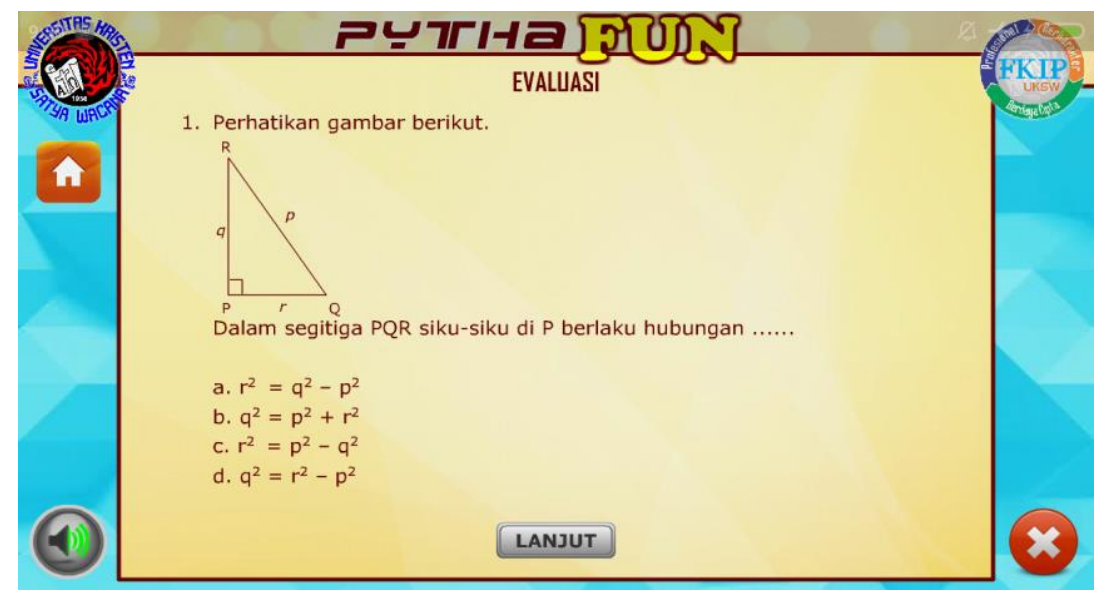

Gambar 10. Soal Evaluasi 
Pengembangan Media Pembelajaran Aplikasi Android Pytha Fun Untuk Teorema Pythagoras SMP, Yohanes Suhendi Pangestu ${ }^{1}$, Danang Setyadi ${ }^{2}$

Mengerjakan soal dengan cara menekan tombol "a", "b", "c" atau "d" pada pilihan jawaban yang tersedia. Setelah itu tekan tombol "Lanjut" untuk mengerjakan soal selanjutnya.

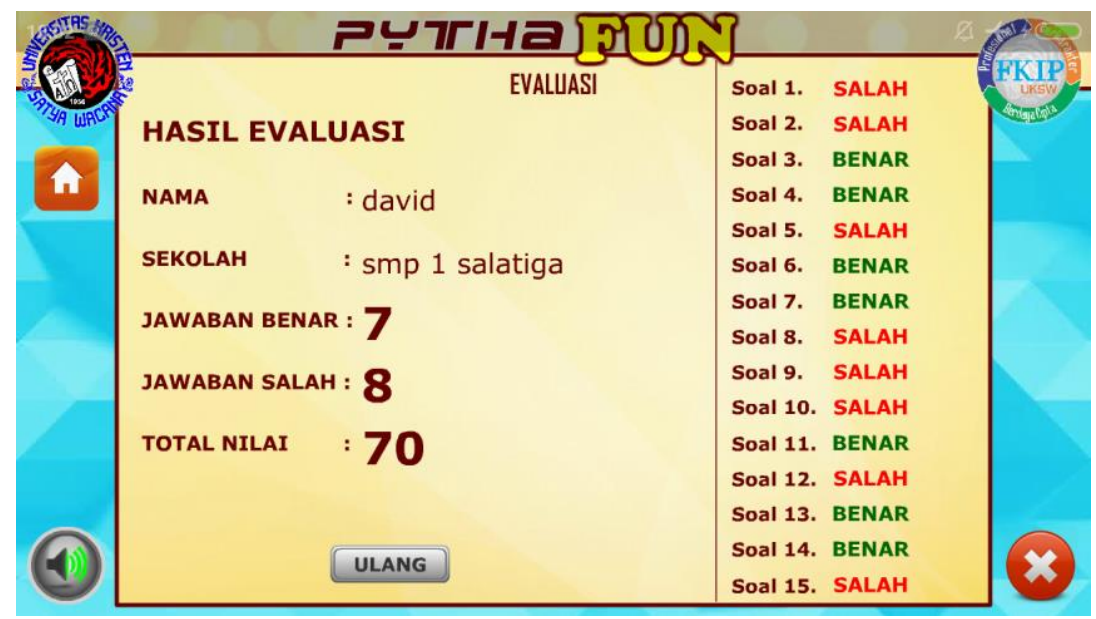

Gambar 11. Hasil Evaluasi

Setelah mengerjakan 15 soal Evaluasi maka akan muncul jumlah soal yang dijawab dengan benar dan jumlah soal yang dijawab dengan salah beserta nomornya dan total nilai yang diperoleh.

Tampilan menu Profil

Menu Profil berisi foto, identitas dan afiliasi pengembang.

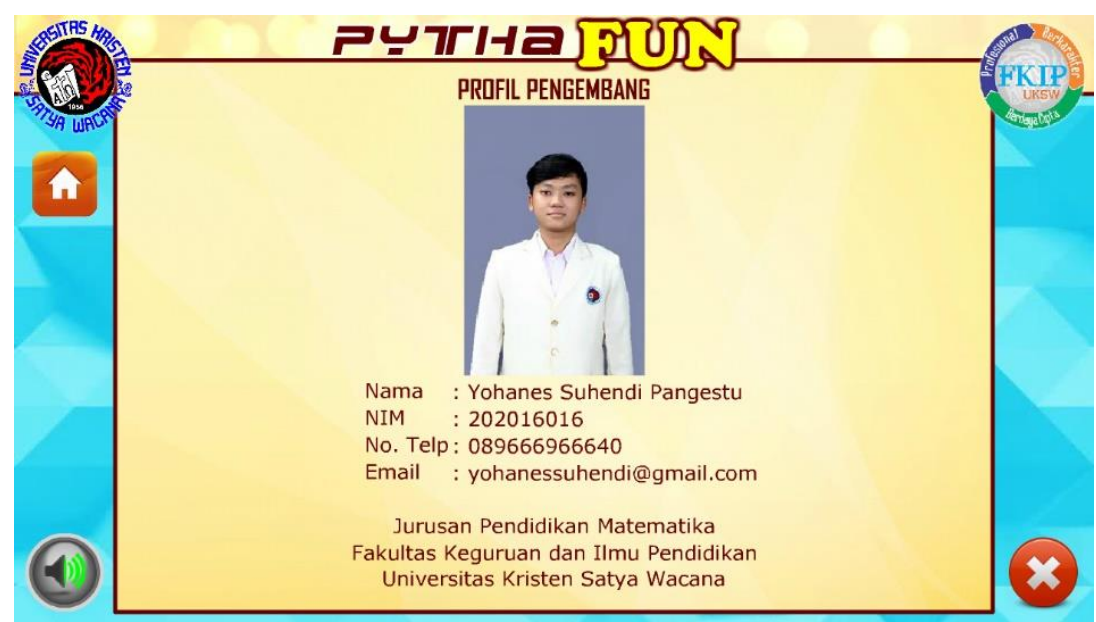

Gambar 12. Profil Pengembang

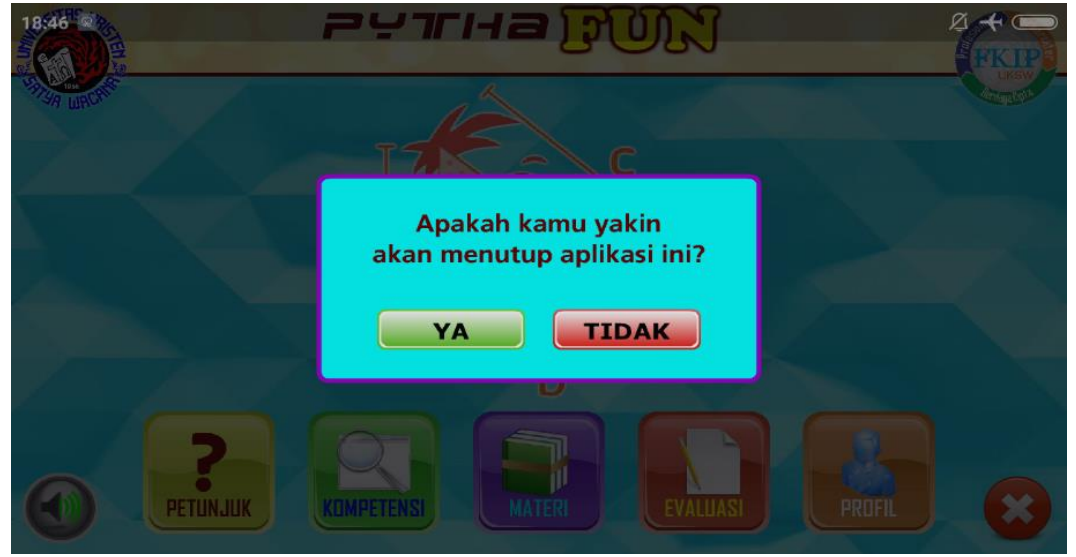

Gambar 13. Menu keluar 
Tombol keluar berfungsi untuk keluar dari aplikasi. Setelah ditekan maka akan muncul menu kecil. Apabila ditekan tombol "Tidak" maka akan kembali ke menu utama, tapi apabila ditekan tombol "Ya" maka akan otomatis keluar dari aplikasi ini.

Aplikasi yang telah dikembangkan selanjutnya dinilai oleh ahli media dan ahli materi. Penilaian ini bertujuan untuk mendapatkan kritik dan saran yang berguna dalam perbaikan media pembelajaran berbasis aplikasi android sebelum diterapkan dalam pembelajaran. Hasil penilaian oleh ahli media diperoleh skor rata-rata 3,9 dan persentase 79,99\% yang termasuk dalam kategori baik. Adapun hasil penilaian oleh ahli materi diperoleh skor rata-rata 4,4 dan persentase $88,89 \%$ yang termasuk dalam kategori sangat baik.

Ahli media dan ahli materi menyatakan bahwa media pembelajaran berbasis aplikasi android sudah layak digunakan dengan revisi. Sebelum melakukan tahap implementasi, media direvisi sesuai dengan kritik dan saran. Berikut ini adalah tampilan media pembelajaran sebelum direvisi dan setelah direvisi yang dapat dilihat pada Gambar 14 dan Gambar 15.

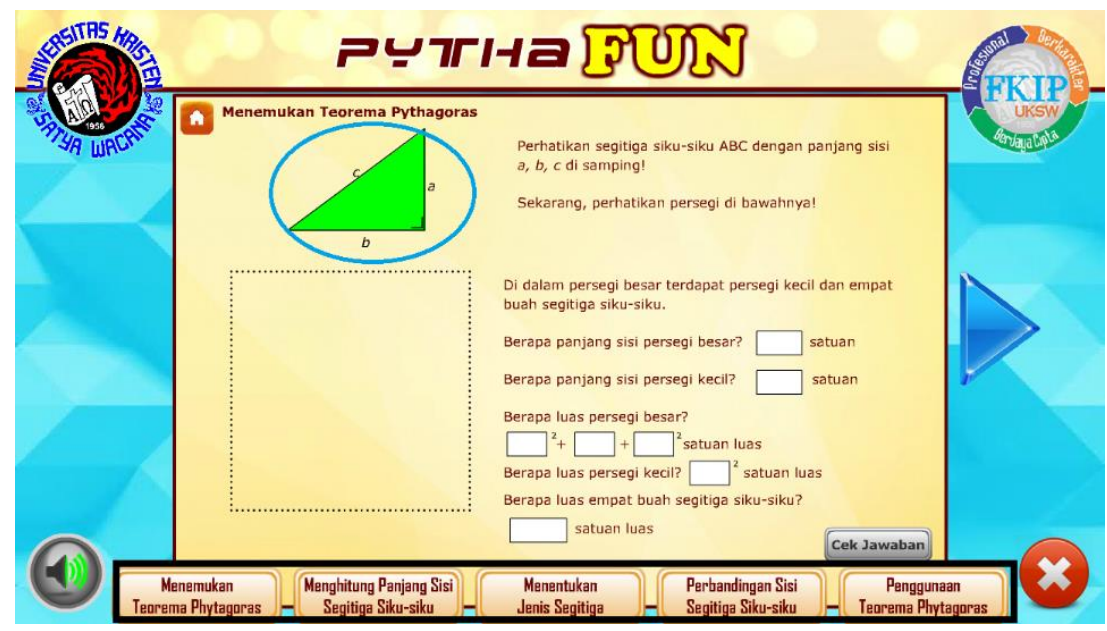

Gambar 14. Tampilan media pembelajaran sebelum direvisi

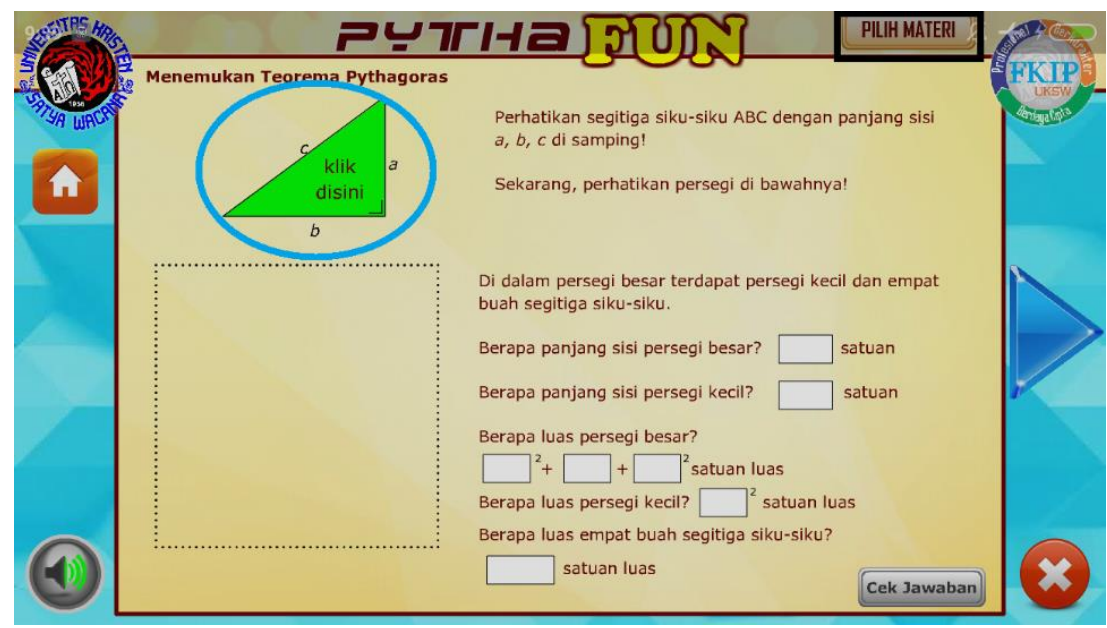

Gambar 15. Tampilan Media Pembelajaran setelah direvisi

Revisi didasarkan atas saran yaitu untuk menambahkan perintah untuk mengklik segitiga berwana hijau sehingga apabila segitiga hijau tersebut telah diklik maka akan muncul animasi segitiga 
Pengembangan Media Pembelajaran Aplikasi Android Pytha Fun Untuk Teorema Pythagoras SMP, Yohanes Suhendi Pangestu ${ }^{1}$, Danang Setyadi ${ }^{2}$

yang masuk di dalam persegi yang memiliki garis putus-putus dan menambah tombol "Pilih Materi" untuk mengganti ke materi lain.

\section{Tahap Implementation (Implementasi)}

Media pembelajaran berbasis aplikasi android telah diterapkan dalam pembelajaran kelas VIII C SMP Negeri 1 Salatiga dengan jumlah 30 siswa. Langkah pertama proses implementasi yaitu mencari tahu pemahaman awal siswa sebelum menggunakan media pembelajaran dalam belajar melalui pre test. Langkah selanjutnya yaitu penerapan media pembelajaran berbasis android kepada siswa yang berfungsi sebagai sumber belajar dan latihan soal materi teorema Pythagoras. Langkah selanjutnya adalah pemberian post test untuk mengetahui pemahaman siswa setelah menggunakan media pembelajaran berbasis android, dari perbandingan hasil pre test dan post test akan diketahui pengaruh yang didapatkan dari penggunaan media pembelajaran berbasis android.

\section{Tahap Evaluation (Evaluasi)}

Tujuan dari tahap evaluasi yaitu mengetahui kelemahan media pembelajaran dan hasil belajar siswa. Hasil dari tahap ini dijadikan dasar perbaikan media pembelajaran berbasis android. Keefektifan media pembelajaran berbasis android diperoleh dari pre test, post test, dan lembar pendapat siswa. Rata-rata nilai pre test dan post test kelas VIII C SMP Negeri 1 Salatiga dapat dilihat pada Tabel 1.

\section{Tabel 1.}

Rata-rata nilai pre test dan post test

\begin{tabular}{|l|l|l|l|l|}
\hline \multirow{2}{*}{ VIII C 30 siswa } & \multicolumn{2}{|c|}{ Pre Test } & \multicolumn{2}{c|}{ Post Test } \\
\cline { 2 - 5 } & Jumlah skor & Rata-rata & Jumlah skor & Rata-rata \\
\cline { 2 - 5 } & 1675 & 55,83 & 2608 & 86,93 \\
\hline
\end{tabular}

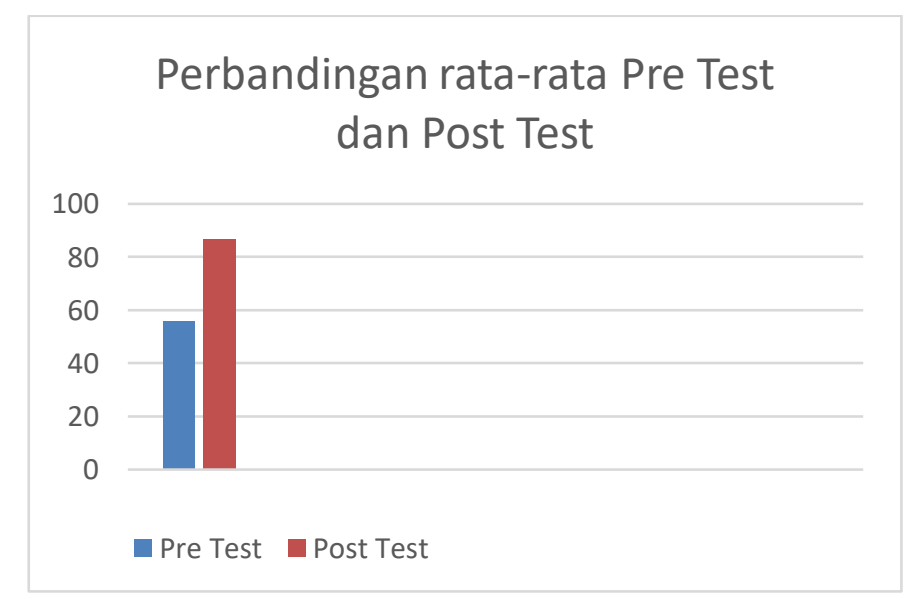

Gambar 16. Perbandingan rata-rata Pre Test dan Post Test

Nilai pre test dan post test dilakukan uji normalitas untuk mengetahui apakah data berdistribusi normal atau tidak. Berikut adalah hasil uji Normalitas menggunakan SPSS : 


\section{Tests of Normality}

\begin{tabular}{|l|l|l|l|l|r|r|r|}
\hline & \multicolumn{4}{c}{ Kolmogorov-Smirnov } & \multicolumn{3}{c}{ Shapiro-Wilk } \\
\hline & Nilai & Statistic & Df & \multicolumn{1}{c}{ Sig. } & Statistic & df & \multicolumn{1}{c}{ Sig. } \\
\hline Hasil & pre test & .114 & 30 & $.200^{*}$ & .968 & 30 & .496 \\
\cline { 2 - 9 } & post test & .129 & 30 & $.200^{*}$ & .957 & 30 & .257 \\
\hline
\end{tabular}

*. This is a lower bound of the true significance.

a. Lilliefors Significance Correction

Tabel 2. Hasil Uji Normalitas

Berdasarkan hasil uji normalitas Shapiro-Wilk nilai Sig. untuk pre test sebesar 0,496 dan post test sebesar 0,257. Karena nilai Sig. untuk pre test dan post test $>0,05$ maka dapat disimpulkan bahwa nilai pre test dan post test berdistribusi normal. Setelah melakukan uji normalitas didapatkan hasil data nilai pre test dan post test berdistribusi normal lalu dilakukan uji Paired Sample T-Test untuk mengetahui apakah ada pengaruh penggunaan media pembelajaran berbasis aplikasi android ini. Berikut adalah hasil uji Paired Sample T-Test menggunakan SPSS:

\section{Paired Samples Test}

\begin{tabular}{|c|c|c|c|c|c|c|c|c|}
\hline \multicolumn{6}{|c|}{ Paired Differences } & \multirow[b]{3}{*}{$\mathrm{t}$} & \multirow[b]{3}{*}{ df } & \multirow{3}{*}{$\begin{array}{l}\text { Sig. (2- } \\
\text { tailed) }\end{array}$} \\
\hline & \multirow[b]{2}{*}{ Mean } & \multirow{2}{*}{$\begin{array}{c}\text { Std. } \\
\text { Deviatio } \\
\mathrm{n}\end{array}$} & \multirow{2}{*}{$\begin{array}{l}\text { Std. } \\
\text { Error } \\
\text { Mean }\end{array}$} & \multicolumn{2}{|c|}{$\begin{array}{c}95 \% \text { Confidence } \\
\text { Interval of the } \\
\text { Difference }\end{array}$} & & & \\
\hline & & & & Lower & Upper & & & \\
\hline $\begin{array}{ll}\text { Pair } & \text { pre test - } \\
1 & \text { post test }\end{array}$ & $\begin{array}{r}- \\
31.100 \\
00\end{array}$ & 12.10970 & 2.21092 & $\begin{array}{r}- \\
35.62184\end{array}$ & $\begin{array}{r}- \\
26.57816\end{array}$ & $\begin{array}{r}- \\
14.06 \\
7\end{array}$ & 29 & .000 \\
\hline
\end{tabular}

Tabel 3. Hasil Paired Sample T-Test

Berdasarkan uji Paired Sample T-Test diperoleh nilai Sig. (2-tailed) $<0,05$ maka ada perbedaan rata-rata antara hasil pre test dan post test yang artinya ada pengaruh media pembelajaran berbasis android Pytha Fun dalam meningkatkan hasil belajar untuk materi teorema Pythagoras.

Setelah mengetahui bahwa adanya pengaruh media pembelajaran berbasis android Pytha Fun dalam meningkatkan hasil belajar untuk materi teorema Pythagoras maka dilakukan analisis N-Gain untuk mengetahui keefektifan media pembelajaran berbasis android.

Tabel 4.

Rata-rata peningkatan nilai siswa.

\begin{tabular}{|l|l|l|l|l|}
\hline & Jumlah skor & Rata-rata & N-Gain & Kategori \\
\hline Pre Test & 1675 & 55,83 & 0,704151 & Tinggi \\
\cline { 1 - 3 } Post Test & 2608 & 86,93 & & \\
\hline
\end{tabular}

Berdasarkan perhitungan menggunakan rumus N-Gain kelas VIII C SMP Negeri 1 Salatiga mengalami peningkatan setelah menggunakan media pembelajaran berbasis android sebesar 0,704151 yang termasuk dalam kategori peningkatan tinggi. Oleh karena itu dapat disimpulkan bahwa media 
pembelajaran berbasis android Pytha Fun pada materi teorema Pythagoras efektif digunakan sebagai media pembelajaran.

Berdasarkan lembar pendapat siswa menunjukkan bahwa media pembelajaran berbasis android Pytha Fun memiliki tampilan yang menarik serta diiringi dengan musik yang tidak membosankan, praktis digunakan karena berwujud software yang terinstal di smartphone sehingga dapat digunakan dimana saja dan kapan saja, memudahkan memahami materi teorema Pythagoras dan setuju apabila media pembelajaran Pytha Fun disusun untuk materi matematika yang lain.

Setelah mendapatkan pendapat siswa yang positif mengenai media pembelajaran berbasis android Pytha Fun maka dilakukan uji kepraktisan untuk mengetahui tingkat kepraktisan media pembelajaran berbasis android Pytha Fun. Uji kepraktisan dilakukan oleh Guru Matematika kelas VIII C SMP Negeri 1 Salatiga. Hasil uji kepraktisan diperoleh skor rata-rata 4,2 dan persentase $84 \%$ termasuk dalam kategori sangat baik. Hal ini dikarenakan media pembelajaran ini berwujud software sehingga mudah dibawa dan digunakan dimana saja saat membawa smartphone serta petunjuknya jelas.

Berdasarkan hasil validasi media dan materi yang telah dilakukan, dapat diketahui bahwa media pembelajaran yang dikembangkan valid. Hal ini dapat diketahui dari persentase skor masingmasing yang memperoleh persentase $\geq 68 \%$. Hasil uji coba skala besar menunjukkan bahwa media pembelajaran yang dikembangkan mampu meningkatkan hasil belajar siswa dalam materi teorema Pythagoras . Selanjutnya, dapat diketahui pula bahwa siswa memberikan respon yang positif terhadap setiap indikator/aspek yang dinilai. Hal ini memperkuat hasil penelitian yang dilakukan oleh Feriatna, Putriani, Deary, Waryanto dan Hadi (2017), bahwa penggunaan media pembelajaran aplikasi android dapat meningkatkan hasil belajar siswa dalam belajar matematika. Secara umum, kelebihan media yang telah dikembangkan adalah 1) tampilan media memberikan kombinasi warna yang beragam sehingga terlihat menarik, 2) mudah untuk dibawa dan digunakan dimana saja , 3) ukuran file media pembelajaran yang tidak terlalu besar, dan 4) kompatible dengan semua versi android. Namun demikian, media yang telah dikembangkan juga memiliki beberapa kekurangan, di antaranya: 1) jumlah soal yang terbatas, 2) soal yang muncul tidak bisa acak dan 3) hanya dapat beroperasi pada system operasi android saja.

\section{KESIMPULAN}

Berdasarkan hasil pembahasan dapat disimpulkan sebagai berikut:

Media pembelajaran aplikasi android Pytha Fun dinyatakan valid digunakan dari segi materi maupun media berdasarkan lembar penilaian yang diberikan kepada ahli media dan ahli materi. Hasil penilaian dari ahli media dan ahli materi menunjukan persentase rata-rata nilai kevalidan memenuhi indeks kevalidan $\geq 68 \%$. Persentase dari segi media adalah 79,99\% dengan kategori baik dan persentase dari segi materi adalah $88,89 \%$ dengan kategori sangat baik sehingga media ini valid digunakan di lapangan. 
Media pembelajaran ini juga praktis digunakan dalam proses pembelajaran karena berwujud software yang terinstal di smartphone sehingga dapat digunakan dimana saja dan kapan saja dibuktikan dengan hasil penilaian yang diberikan kepada guru mata pelajaran Matematika menunjukan persentase rata-rata nilai kepraktisan sebesar $84 \%$ dengan kategori sangat baik sehingga media ini praktis untuk digunakan dalam proses belajar mengajar.

Hasil dari uji paired sample t-test adalah kurang dari 0,05 yang menunjukkan terdapat perbedaan dari hasil nilai siswa yaitu dengan rata rata nilai Pre Test 55,83 meningkat menjadi 86,93 pada nilai Post Test, lalu hasil dari analisis N-Gain mengalami peningkatan setelah menggunakan media pembelajaran berbasis android sebesar 0,704151 yang termasuk dalam kategori peningkatan tinggi maka media ini efektif digunakan untuk meningkatkan hasil belajar siswa dalam materi teorema Pythagoras. Berdasarkan lembar pendapat siswa mendapatkan respon positif untuk media pembelajaran serta disarankan agar media pembelajaran berbasis android agar dikembangkan untuk materi lainnya dan dikembangkan untuk system operasi lainnya seperti untuk system operasi IOS.

\section{DAFTAR PUSTAKA}

Adinawan, Sugiono. (2006). Matematika SMP Jilid 2A Kelas VIII. Jakarta: PT. Gelora Aksara Pratama

Arsyad, (2002). Media Pembelajaran , Jakarta: PT RajaGrafindo Persada

Branch, RM, \& Kopcha, TJ (2014). model desain pembelajaran. Dalam Handbook penelitian tentang komunikasi pendidikan dan teknologi

Daulay, Jamilah (2013). Upaya Meningkatkan Hasil Belajar Siswa Dengan Model Pembelajaran Langsung Menggunakan Macromedia Flash 8 Pada Materi Teorema Pythagoras Di Kelas VIII Smp N 35 Medan Tahun Ajaran 2012/2013. Undergraduate thesis, UNIMED.

Dr. Rusman, M.Pd. (2012). Belajar dan Pembelajaran berbasis Komputer, Bandung: Alfabeta.

Fahmi, S. (2014). Pengembangan Multimedia Macromedia Flash Dengan Pendekatan Kontekstual Dan Keefektifannya Terhadap Sikap Siswa Pada Matematika. Jurnal Agrisains, 5(2).

Feriatna, T., dkk (2017). Pengembangan Aplikasi Android Sebagai Media Pembelajaran Pada Materi Peluang Untuk Siswa SMA Kelas X. Lemma : Letters of Mathematics Education, 4(1).

Muyaroah, S., \& Fajartia, M. (2017). Pengembangan Media Pembelajaran Berbasis Android dengan menggunakan Aplikasi Adobe Flash CS 6 pada Mata Pelajaran Biologi. Innovative Journal of Curriculum and Educational Technology, 6(2), 22-26. Retrieved from https://journal.unnes.ac.id/sju/index.php/ujet/article/view/19336

Putriani, Deary, Waryanto, Nur Hadi (2017). Pengembangan Media Pembelajaran Berbasis Android Dengan Program Construct 2 Pada Materi Bangun Ruang Sisi Datar Untuk Siswa Smp Kelas 8. S1 Thesis, Uny.

Rachmawati. (2014). Pengembangan Media Pembelajaran Interaktif Matematika Berbasis Pendidikan Karakter Dengan Software Adobe Flash Cs3 Pada Pokok Bahasan Teorema Pythagoras. 
Pengembangan Media Pembelajaran Aplikasi Android Pytha Fun Untuk Teorema Pythagoras SMP, Yohanes Suhendi Pangestu ${ }^{1}$, Danang Setyadi ${ }^{2}$

Rifai (2017). Pengembangan Media Puzzle untuk Pembuktian Teorema Pythagoras.

Wardana, Handoko Aji (2016). Pengembangan Multimedia Berbasis Aplikasi Adobe Flash Cc 2015 Pada Pembelajaran Tematik Integratif Subtema Manusia Dan Lingkungan Kelas V Di Sekolah Dasar. Bachelor thesis, Universitas Muhammadiyah Purwokerto.

Widyanto E dan Kurniasari I (2016). Pengembangan Media Pembelajaran berbasis Adobe Flash Professional CS 6 pada Materi Teorema Pythagoras untuk Siswa Kelas VIII.

Winaldi, W., Roza, Y., \& Maimunah, M. (2019). Desain Sumber Belajar Matematika Berbasis Aplikasi Android Pada Materi Perbandingan Trigonometri Segitiga Siku-Siku. Jurnal Cendekia: Jurnal Pendidikan Matematika, 3(2), 513-524.

Yuliana, Pratiwi , Anwar (2018). Pengembangan Media Interaktif Matematika Berbasis Macromedia Flash. 